\title{
Analysis on English Learning Motivation Decline of Non-English College Students of Colleges and Universities in Minority Regions-Taking Xichang College as an Example
}

\author{
Shanglian Yao \\ Department of Foreign Affairs, Xichang College, Xichang 615013, China
}

Keywords: English Learning Motivation. Motivation Decline. Suggestions

\begin{abstract}
Motivation decline and motivation loss" is a fairly obvious phenomenon and a comparatively new problem in research field of second language acquisition and foreign language learning. This paper on the basis of Dornyei's demotivation theory takes research results at home and abroad as references, discusses English learning motivation decline of non-English college students of colleges and universities in minority regions through questionnaire surveys to students, and puts forward feasible measures and suggestions, aiming to further stimulate and maintain students' English learning enthusiasm, and to improve the learning effects.
\end{abstract}

\section{Introduction}

Motivation is one of the key factors of English learning success. Each language learner may more or less suffer learning failure and successful learners are always those who have relatively stronger learning ability and learning motivation. As what Dornyei has pointed out that in English learning process, learners will be impacted by not only external positive factors but also the external negative factors. However, researchers at home and abroad all pay more attention to the positive factors but little attention to the negative ones. Actually we usually find out in English teaching that new students every year will vow solemnly to learn English well when entering colleges and universities, and make a series of plans. It won't be long before a considerable part of them show motivation decline in English learning. Some students even loss their learning motivation completely. There is problem of motivation decline in college English learning all along. Most students have their English learning motivation declined year after year. This study discusses whether there exists motivation decline phenomenon in college English classes of non-English students in minority regions. It also analyzes the relevant factors that have caused this phenomenon and measures that should be taken to deal with these problems.

\section{Research Background}

Motivation is generally defined as the inner process of stimulating, guiding and maintaining. In language learning field motivation refers to the combination of wish and endeavor of achieving language learning goals. It will be impacted by positive factors and weakened by negative factors. Dornyei named motivation decline as demotivation which means counteracting the environmental inducement and class events of students' existing motivation, and reducing or weakening the special external force of certain behaviors' or behavioral intentions' motivation basis.

\section{Research methods}

Objects of this study are freshmen and sophomores of non-English major in Xichang College of Yi Autonomous Prefecture of Liangshan, Sichuan. They come from 15 majors of various departments with 40 freshman of 2013 level and 68 sophomore of 2014 level (actually only 93 effective questionnaires). The reason why I only choose freshmen and sophomores of non-English major is that English course is only opened for freshmen and sophomores of non-English major in this college. This study takes previous research results as references (Wu Benhu, 1997; Oxford, 1998; Dornyei, 
2001), adopts questionnaire survey tools, combines qualitative and quantitative research methods, summarizes students’ questionnaires and conducts basic statistical analysis on data.

\section{Results and discussion}

\section{Motivation decline factors analysis}

Table 1 English learning motivation decline factors

\begin{tabular}{|c|c|c|c|c|c|c|c|}
\hline Categories & & \multicolumn{6}{|c|}{ Proportion } \\
\hline \multirow{3}{*}{$\begin{array}{l}\text { 1. Degree of your English } \\
\text { learning motivation decline? }\end{array}$} & $\begin{array}{l}\text { options } \\
\text { students }\end{array}$ & $\mathrm{A}$ & B & $\mathrm{C}$ & $\mathrm{D}$ & $\mathrm{E}$ & $\mathrm{F}$ \\
\hline & freshmen & 8.57 & 11.43 & 40 & 31.43 & 8.57 & \\
\hline & sophomores & 1.59 & 36.51 & 33.33 & 20.63 & 7.94 & \\
\hline \multirow{2}{*}{$\begin{array}{l}\text { 2. Which one of the following } \\
\text { motivation decline factors } \\
\text { related with teachers affects you } \\
\text { most? }\end{array}$} & freshmen & 40 & 22.86 & 11.43 & 17.14 & 5.71 & 2.85 \\
\hline & sophomores & 31.75 & 20.63 & 15.87 & 14.29 & 9.52 & 7.94 \\
\hline \multirow{2}{*}{$\begin{array}{l}\text { 3. Which one of the following } \\
\text { motivation decline factors } \\
\text { related with students affects you } \\
\text { most? }\end{array}$} & freshmen & 11.43 & 45.71 & 20 & 14.29 & 8.58 & 0 \\
\hline & sophomores & 14.29 & 46.04 & 20.63 & 15.87 & 3.17 & 0 \\
\hline \multirow{2}{*}{$\begin{array}{l}\text { 4. Which one of the following } \\
\text { motivation decline factors } \\
\text { related with textbooks affects } \\
\text { you most? }\end{array}$} & freshmen & 22.86 & 0 & 37.14 & 11.43 & 28.57 & 0 \\
\hline & sophomores & 23.81 & 7.94 & 25.4 & 14.29 & 26.98 & 1.58 \\
\hline \multirow{2}{*}{$\begin{array}{l}\text { 5. Which one of the following } \\
\text { motivation decline factors } \\
\text { related with social background } \\
\text { affects you most? }\end{array}$} & freshmen & 11.43 & 8.57 & 40 & 22.86 & 4.29 & 2.85 \\
\hline & sophomores & 6.35 & 11.11 & 41.27 & 31.75 & 6.35 & 3.17 \\
\hline \multirow{2}{*}{$\begin{array}{l}\text { 6. In conclusion, what do you } \\
\text { think is the main reason for your } \\
\text { English learning motivation } \\
\text { decline? }\end{array}$} & freshmen & 17.14 & 34.26 & 2.85 & 42.86 & 2.85 & 0 \\
\hline & sophomores & 22.22 & 41.28 & 12.7 & 20.63 & 3.17 & 0 \\
\hline
\end{tabular}

According to the above table, freshmen's decline degrees of first category "Degree of your English learning motivation decline" are respectively C (much decline) 40\%, D (serious decline) 31.43\%, B (a little bit decline) 11.43\%, A (no decline) 8.57\% and E (complete decline) 8.57\%. Sophomores' decline degrees are respectively B (a little bit decline) 36.51\%, C (much decline) 33.33\%, D (serious decline) 20.63\%, E (complete decline) $7.94 \%$ and A (no decline) 1.59\%. It can be concluded that English learning motivation decline is a universal phenomenon because the English learning motivation of both freshmen and sophomores is declining. The degree of sophomores is greater than that of freshmen only because freshmen are full of longing and yearning for new college life and will all vow solemnly to learn English well. However, tense and busy study habits in middle school may more or less affect them to study. Sophomores after one year of college life become familiar with the environment and will show passive phenomena like indolence, early leave and absence. They hold an attitude of keeping out of the affair and don't participate in classroom teaching actively.

As for the second category "Which one of the following motivation decline factors related with teachers affects you most”, there is no too many differences between freshmen and sophomores for they all think option A (teaching strategy) affects them most with proportion as respectively $40 \%$ and 31.75\%. Option B (personal character) ranks the second. Students all like to compare and discuss their teachers. Some students think that teachers in college are not as tender as their teachers who care for them in middle schools. They pay little attention to teaching strategy. In class, teachers merely repeat what the book says by explaining vocabulary, grammar and text translation, ask students to do homework and finally elaborate all the exercises without any new idea. They blindly criticize 
students with a straight face, bad pronunciation and intonation, and rapid speaking speed which make students unclear. They don't make good preparation for class, sometimes are even late for class, frequently bring bad mood to class, don't communicate with students and disappear after class.

As for the third category "Which one of the following motivation decline factors related with students affects you most”, choices of freshmen and sophomores are consistent with each other. They all think the sequence of influence degree is B (personal endeavor), C (learning target), D (learning strategy), A (individual information), and E (personal character). Obviously, students have realized their own problems. Real reasons for English achievements are their insufficient endeavor, time and energy of learning English. They don't make detailed learning plans or targets. Even though they do, the passion of learning can't last for several days and then will become "smoke and ashes". Some students also blame their bad memory because they usually forget English words. They pay no attention to learning strategy, use no memory rule, and rarely remember or guess meaning in virtue of circumstances or contexts. In addition, students may suffer so many times of failure when exploring learning strategies because of personal differences. At the same time, pressure from students, family and social will heavily hurt their pride and self-confidence, resulting in learning motivation decline.

In factor of "Which one of the following motivation decline factors related with textbooks affects you most", freshmen think that the length of textbooks impacts them most. As for freshmen, texts in middle schools are short, readable and easy for reciting while texts in colleges are all harangues with too many new words which are so hard for students. Sophomores after experiencing one year of college life pay more attention to personal communicative activities, so they may think that present textbooks lack enough communicative activities and pay little attention to students' ability of using language independently. They also hold that textbook contents are not related with real life without sufficient language materials.

As for the factor "Which one of the following motivation decline factors related with social background affects you most", the proportion of freshmen and sophomores are basically identical. They all think that $C$ (future work) affects them most. D (teaching facilities) ranks the second. Students nowadays are realistic. Non-English major students will think that English isn't their major and they won't engage in work related with English in the future, so learning English at present is of no use. It will be unknown how many students will learn English initiatively but for college's requirements. Moreover, Xichang College is located in remote minority regions with limited conditions and poor equipment. College English classes are of too many students (average number as more than 60 or 70 students in a class), which isn't good for English learning. College barely provides platform and settings for students to communicate in English. "English corner" in the past has become history.

According to the last factor "In conclusion, what do you think is the main reason for your English learning motivation decline”, There are differences with previous research achievements. Most previous researches have showed that more than half motivation decline factors are related with teachers, while in this study only $17.14 \%$ (freshmen) and $22.22 \%$ (sophomore) factors are related with teachers.

\section{Enlightenment and suggestions}

Basing on previous analysis, we can conclude students' English learning motivation decline as internal factors and external factors. Internal factors mainly refer to students' personal endeavor degree, learning target, learning strategy and personal character. External factors mainly include teachers, textbooks and social background. This paper from perspective of internal factors and external factors will put forward some suggestions for college students' English learning motivation decline of colleges and universities in minority regions.

\section{Internal factors}

Just as language learning is an endless accumulative process, learners' character is also a relatively stable and unchangeable personal difference factor. Therefore, if students want to recover learning motivation from internal factors, they have to consciously restrain and regulate themselves. Of course, it can't be achieved in an action. They must actively face it in thoughts and pay more attention to it. 
More confidence they have in learning English, the stronger their sense of achievement will be. So their motivation isn't easy to be declined. In learning process, students must overcome anxious psychology, cultivate interest in learning English and constantly gain more confidence in progress.

\section{External factors}

Although this study has showed that students don't regard teachers as key factors of their English learning motivation decline, it is obvious that teachers' impact is profound and everlasting. Teachers are inevitably able to change students' attitude toward English. Similarly, teachers can shake the learning attitude of members in learning teams and have a significant impact on students' confidence.

Minority regions are faced with blocked information and several behindhand aspects. Teachers should firstly reinforce their own professional quality, improve their teaching ability, constantly update their knowledge level, and promote teaching. Secondly, teachers should show their passion for work. A teachers with passion for work can not only has sense of responsibility and mission but also be able to affect students and make them feel that they should treat learning with passion like teacher. When making preparations, teachers should fully take students' experience and attitude into consideration. Contents of classroom teaching should get close to real environment of language application as much as possible, and provide practicability and enjoyment of knowledge. Teachers should communicate with students after class and build effective information feedback mechanism. In addition, teachers should care for all students especially those with low-level language, take these students' receptivity and actual requirements into consideration, continuously encourage students' progress, and strengthen their sense of confidence and achievements. In fact, poor students need more affirmation of their progress. Teachers should also respect students, enhance communication out of class, don't take own course, listen to students, adopt proper suggestions, and build trustful and respectful relationship with students.

\section{Conclusion}

The research results in this paper are different from Dornyei's researches which generally hold that teachers are the strongest factors of motivation decline. This study has showed that factors related with students and social background affect students' English learning motivation decline most, because the research objects in this paper come from colleges in remote minority regions which have their own particularity. As for such kind of particularity, only particular measures and strategies can serve colleges and universities in minority regions better.

\section{Acknowledgments}

This paper is one of the research results of postgraduate scientific research project named "Analysis on English Learning Motivation of Non-English College Students of Colleges and Universities in Minority Regions” in Xichang College.

\section{References}

[1] Dornyei, TeaTeaching and Researching Motivation, Harlow: Person Education Limited, 2001

[2] Oxford, R. 1998: The unraveling tapestry: Teacher and course characteristics associated with demotivation in the language classroom. Demotivation in foreign language learning. Paper presentd at the TESOL'98 Congress, Seattle, WA, March

[3] Hu Weixing, Cai Jinting: Model building of English learning motivation decline, Foreign Language Teaching, 2010.5. vol.31 (3)

[4] Tang Wenli: Analysis on English learning "motivation decline” of non-English major students, Foreign Language Teaching, 2012.1.vol.33 (1) 
[5] Wu Benhu: Speech motivation of verbal communication in class, Journal of Zhejiang Normal University, 1997.5

[6] Zhang Zhe: Analysis on English learning motivation decline factors of non-English major students, Master's dissertation, Jilin University, 2007.

[7] Zhuang Xiaorong: Factors of college students' English learning motivation decline. Journal of Anshan University of Science and Technology, 2011. 